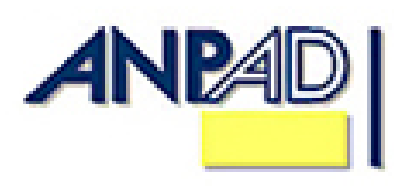

Available online at http://www.anpad.org.br/bar

BAR, Rio de Janeiro, v. 11, n. 1, art. 6, pp. 107-124, Jan./Mar. 2014

\title{
Reflections on Actor-Network Theory, Governance Networks, and Strategic Outcomes
}

\author{
Ludmilla Meyer Montenegro \\ E-mail address: ludmilla2907@gmail.com \\ Universidade Federal de Sergipe - UFS \\ Av. Vereador Olímpio Grande, s/n, Centro, 49500-000, Itabaiana, SE, Brazil. \\ Sergio Bulgacov \\ E-mail address: s.bulgacov@gmail.com \\ Fundação Getúlio Vargas - FGV-SP \\ Av. 9 de Julho, 2029, Bela Vista, 01313-902, São Paulo, SP, Brazil.
}

Received 15 February 2013; received in revised form 14 April 2013; accepted $1^{\text {st }}$ May 2013; published online $2^{\text {nd }}$ January 2014. 


\begin{abstract}
In an attempt to instigate discussion in the areas of organizational studies and strategy, this essay focuses on themes related to Governance, Actor-Network Theory, and Strategic Outcomes. We seek to expand understanding of the Governance Network Theory by proposing the inclusion of human and non-human actors from the Actor-Network Theory in its scope. Recent studies concerning the notion of heterogeneous networks have demonstrated the importance of non-human actors for understanding social and organizational phenomena. When combined with a network perspective, strategy is seen as something that people within organizations do and not something that organizations have (Johnson, Langley, Melin, \& Whittington, 2007). Networks require interaction, movement, and process; i.e., the active participation of actors involved. Decision making and activities are continuously realized based on the ties between actors and the content they deal with. We believe that this theoretical framework will reveal aspects and issues taken for granted that should be incorporated in the Governance Network Theory's empirical scope of analysis, primarily for research in plural and complex organizations permeated with ambiguous and power-related issues.
\end{abstract}

Key words: governance networks; strategizing; strategic outcomes; actor-network theory; education. 


\section{Introduction}

This essay's objective is to develop a deeper understanding of governance (its mechanisms and networks) and strategic outcomes, based upon governance network theory (Rhodes, 1997, 2007), strategic outcomes (Bulgacov, Souza, Prohmann, Coser, \& Baraniuk, 2007; Matitz, 2009), strategy as practice (Golsorkhi, Rouleau, Seidl, \& Vaara, 2010; Johnson, Langley, Melin, \& Whittington, 2007), and Actor-Network Theory (Latour, 1994a, 1994b, 1996a, 2000, 2001, 2005; Law, 1992; Wessells, 2007).

We suggest that the governance network theory is made more robust if non-human actors are included in its theoretical scope (Latour, 1994a, 1996b, 2000, 2001, 2005). Recent studies concerning the notion of heterogeneous networks have demonstrated the importance of non-human actors for understanding social and organizational phenomena (Andrade, 2005; Latour, 1994a, 1996b; Tureta, Rosa, \& Santos, 2006; Wessells, 2007).

Denis, Langley and Rouleau (2007) compared potential contributions from social practice theories, convention theory and actor-network theory (Golsorkhi et al., 2010). According to Jarzabkowski (2010), the actor-network theory represents one viable approach for studying how nonhuman artifacts are engaged in Strategy as Practice.

It is important to clearly define what we mean by social. According to Ator-Network Theory (ANT), human actors are not the only actors that compose the social sphere, since non-human actors are also part of it (Latour, 1994b, 2001, 2005). Therefore, ANT's contribution to social theory is in the recognition that social actors and social relationships do not exist without non-human actors (Whittle \& Spicer, 2008), and if studied in isolation from each other, important dynamics can be missed. Law (1992) also corroborates this issue by emphasizing that social is not simply human related. When Czarniawska (2003) explained social constructionism, she mentioned some authors (Berger, Luckmann, Latour, Rorty, Moscovici and others) that hold a similar definition of social. An artificial dichotomy should not be created between natural and social actors. And most importantly: material matters are included in this natural/social world.

Furthermore, some studies (Barad, 2003; Latour, 2004; Orlikowski \& Scott, 2008; Slife, 2004; Suchman, 2007) have shed light on the need to investigate the social aspects of organizations in their entirety, from a more holistic perspective. This means that material aspects should also be considered. This is from the idea that material aspects are not just tools to be used to accomplish tasks, but are also constitutive of both activities and identities (Orlikowski \& Scott, 2008). As Yanow (2006) described, policy implementation can be appreciated as a process by which agency and political meanings are communicated. This happens through artifacts: spoken and written language, of course, but also acts and objects, including physical structures, such as buildings, associated with agency.

It is important to highlight that, from this perspective, the strategic world constitutes a genuine social reality that is created and recreated in the interactions between multiple actors within and outside of organizations (Golsorkhi et al., 2010). Even though strategizing involves abstraction and the formulation of intentionality, it is still a socio-material and political process that involves the use of tools, especially language (Tsoukas, 2010). Due to this, histories, repertories, tools and artifacts which refer to strategy are not disproven by ambiguity; instead they should be reinterpreted given any new situation (Grand, Rüegg-Stürm, \& Arx, 2010).

As such, this work seeks to contribute to the thought and development of the Actor-Network Theory, to enhance understanding of strategic outcomes and organizational governance networks. Its empirical basis extends from the perspective of the actions and relationships of the multiple actors involved, both human and non-human.

These perspectives were chosen because we believe they recognize governance as focused on organizational beliefs, practices, traditions, and dilemmas. When combined with a network 
perspective, of public and private actors, strategy is seen as something that people within organizations do and not something that organizations have (Johnson et al., 2007). Moreover, non-human actors should also be considered and investigated, in addition to the human actors that comprise networks. This can possibly offer an improved comprehension of organizational realities.

\section{Recent Debates on the Governance Theme}

In the area of organizational studies and strategy, it is common to link the term governance with corporate governance. However, not all studies in this area are about corporate governance. Many times, focus is on governance that is more sociological in nature in order to investigate organizational phenomena.

It is important to clarify the term governance, since it is not easily understood. Indeed, in Political Science and Sociology there is still considerable debate about the most appropriate definition of the term. Hirst and Thompson (1995) believes that despite the ambiguity that permeates the term governance, the majority of definitions tend to converge on a notion of a post-policy resource for efficient regulation and responsibility. According to this author, many examples of the term governance refer to situations that reveal a true threat to conventional forms of democratic government or propose to leave democracy behind.

Even though governance isn't clearly defined, it has been extensively discussed. Olowu (2002) mentioned that discourse about governance has continued even while controversy over its definition has endured. For Ezzamel and Reed (2008) governance has emerged from a grand focus of continuous debates about the organizational practices and forms by which we live and order our lives. Hirst and Thompson (1995) asserts that the increase in the use of the governance concept can be seen as a reaction to changes in political practices, together with realities that are also changing. These involve, among other things, increasing globalization and networks that cross over the division between state and civil society. These developments demand discourse about how to govern in an ever more complex world. Kjaer (2004) also stresses that despite inherent problems with the theme, governance is a popular and contemporary topic. Envisioning governance as a process that extends beyond the notion of government goes beyond rehashing old ideas. It touches on political implications of social change, since it shifts to a new focus on political institutions in a constantly changing world.

It is important to note that currently, governance is not used as a synonym for government, as governance actually signifies a change in the meaning of government. It refers to a process for governing, a modified condition of the ordered rule, or a new method by which society is governed (Rhodes, 1997). According to the same logic, Kjaer (2004) emphasizes that government assumes a subject (actor), while governance is the result of completed actions as a form of social coordination. Thus, the concept of governance is more closely associated with a procedural and result-oriented logic, which coincides with the other approaches used in this article: Actor-Network Theory (Latour, 1994a, 1996b) and strategic outcomes (Bulgacov et al., 2007; Matitz, 2009).

The notion of government isn't enough to explain some questions about what happens in organizations. This process for governing involves questions about the daily life in organizations, many times about informal aspects that occur in quotidian organizational activities.

Another clear point of distinction between governance and government is that governance is a wider phenomenon. That is because it doesn't just include governmental organizations, but also informal and non-governmental mechanisms (Kjaer, 2004; Rhodes, 1997). Actually, governance can occur without government when regulatory mechanisms function effectively within a sphere of activity, even though formal authority isn't present. 


\section{Notions about Governance Networks}

The notion of governance as network practices comes from Rhodes (2007):

A decentred approach undercuts the idea of network steering as a set of tools by we can manage governance. If governance is constructed differently, contingently and continuously, we cannot have a tool kit for managing it. This line of reasoning challenges the idea of expertise as a basis for policymaking. An interpretive approach encourages us to give up management techniques and strategies for a practice of learning by telling stories and listening to them (p. 1257).

Governance in the form of self-organized networks doesn't seem to occur through planning. These networks are self-forming and, based upon observations, are gaining more strength and autonomy over time. Use of the concept of governance networks is increasing (Sorensen \& Torfing, 2005). It is clear that a shift is occurring and that it will intensify in the future. Recent statements by various authors (Hirst \& Thompson, 1995; Sorensen \& Torfing, 2005) show that it doesn't make sense to turn back, revise questioning, or reconstruct the initial concept of government. At this moment what seems crucial to understanding this movement is to try to identify and comprehend these networks, map the governance mechanisms involved, and define the public and private actors that participate, all through empirical research.

Sorensen and Torfing (2005) introduced some positive points for instigating research into governance from the network perspective, such as: (a) governance networks have great potential for proactive governance, in that multiple actors are more capable of quickly identifying new opportunities and problematic policies, and also to produce flexible responses that correspond to the complexity and variety of fixed conditions; (b) governance networks are sought as important instruments for coalescing information, knowledge and evaluations that can qualify policy related decisions. Actors within these networks generally have relevant detailed knowledge for making these kinds of decisions, and when knowledge from all involved actors is combined, it represents a significant basis for making intelligent choices between feasible options; (c) governance networks establish a frame of reference for consensus building or at least for dealing with conflicts between stakeholders; (d) governance networks supposedly reduce the risk of resistance to implementation, because when actors are involved, they are more likely to be supportive.

Rhodes (1997) refers to the self-organized inter-organizational networks characterized by interdependence, resource exchange, game rules, and significant autonomy from government. Selforganized means that the network is autonomous and self-governed. This autonomy doesn't necessarily imply liberty, but rather self-responsibility. As such, integrated networks are resistant to governmental control, and instead develop their own policies and shape their environments (Rhodes, 1997).

Self-organized governance networks can impede implementation and have a negative impact on the capacity for control, or they can enhance the efficiency of policy implementation. In the new theory of governance, networks are seen to have equal possibility of positive as well as negative impacts on management capacity (Peters, 2000). Thus, it is important to determine how these networks are formed, who forms them, and how they function, since they have such direct impacts on governance.

The more we know about networks, the better we understand governance dynamics and its relationships with government, informal mechanisms, and private actors. Hence, we believe that qualitative research is essential for understanding some of the questions related to governance networks. This is because a qualitative approach, from the first moments of research, brings certain insights from the field that are highly important for understanding the reality under scrutiny. It also helps to define the categories for analyzing data. 
Sorensen and Torfing (2005) explain that governance networks can be formed in different ways. They can self-develop or be initiated by those at higher organizational levels. They can emerge between contacts with weak, or informal, ties or be more rigid and formal. They can also exist within or between organizations, have short life spans or be relatively permanent, and be specific (a single sector) or general (society) in scope.

Ezzamel and Reed (2008) also offer an interesting definition of governance. According to them, "governance is a multi-level, multi-dimensional regulative practice and form that is always mediated through particular socio-historical and spatial contexts" (Ezzamel \& Reed, 2008, p. 600).

Based upon what we have expressed thus far, it is clear that understanding governance networks isn't simple, but also isn't impossible. Inquiry into the theme must be done with transparency, and it is essential to understand the role actors have in networks. When aspects are as clear for network actors as they are for stakeholders and private citizens, a coherent conception of governance networks will be achievable.

The notion of governance used in this work is primarily aligned with the definition from Rhodes (1997), but also echoes Sorensen and Torfing (2005), Ezzamel and Reed (2008), and Kjaer (2004). Rhodes (1997) definition is most interesting in that it focuses on networks, offering greater coherence for investigating governance by involving the various public and private actors that self-organize into networks.

For empirical research, it is relevant to identify the actors involved and understand their activities and practices, to illuminate the networks and governance mechanisms of the organizational reality under scrutiny. We believe that in order to understand actors' quotidian activities, and consequently the strategic practices that exist in the studied reality, it is fundamental to understand governance networks.

We also assert that not only do people participate and influence governance and organizational strategies, but objects, artifacts, documents, and plans also have potential roles. Many times these nonhuman actors are not investigated and, as a result, some essential aspects for comprehending governance and organizational strategic outcomes are not revealed.

\section{Actor-Network Theory}

An actor is called an actor-network, this means that it represents a greater source of uncertainty about the origin of the action (Latour, 2005). For Latour (2001) actions are not simply a human attribute, but instead an association between agents. Actors' temporary roles can be attributed directly to agents because they are found in a process of permuting competences, offering each other new possibilities, new objectives, and new functions. Latour (2001) believed that perhaps intentional actions and intentionality aren't properties of objects or people. They are institutional properties. Objects can only contrast subjects, and vice versa. Non-humans can only interact with humans on account of key processes, such as translation, articulation, delegation, and displacement to other areas or levels.

Since terminology involved in Actor-Network Theory is extensive, we are including, before the end of this section, a table to briefly describe four essential concepts to help grasp its nature: actor, actor network, symmetry, and translation.

According to Alcadipani and Tureta (2008), the origins of the Actor-Network Theory are linked to a handful of authors, including Michel Serres, Algirdas Greimas, Isabel Stengers, Gabriel Tarde and Harold Garfinkel (See: Latour, 2005; McLean \& Quattrone, 2006). These authors affirm that the initial sources of inspiration for the theory are semiotic/structuralism, phenomenology, and ethnomethodology (Calás \& Smircich, 1999). 
The origin of this approach can be found in the need for a new social theory adjusted to studies in science and technology (Callon \& Latour, 1981). For Latour (2005), we have to make social science and technology compatible. Therefore, the Actor-Network Theory is not just a social theory, but rather a theory of how to study social phenomena (Czarniawska, 2006).

It is important to understand that working with Actor-Network Theory can be time-consuming. Activities are constantly interrupted, disrupted, and impeded by the five types of uncertainties.

Latour (2005) stressed that it is possible to construct five great uncertainties from the great institutions of social sciences:

. the nature of groups: there are many contradictory forms by which actors receive an identity;

the nature of actions: in each course of action a large number of agents seem to move and disrupt original objectives;

. the nature of objects: the types of agencies participating in interactions seem to be all-inclusive;

the nature of facts: the connections natural sciences have with the rest of society seem to be a constant source of conflict;

finally, about the types of studies made under the label of social science, it is never clear in exactly what sense social sciences are empirical (Latour, 2005, p. 22)

Thus, this type of research is neither simple nor immediate. Quite the contrary, it requires attention and investigative effort.

The notion of groups in the Actor-Network Theory is actually unusual. In this theory, groups are created and recreated. If this doesn't happen, then the notion of group is lost. This aspect corresponds to the perspective of governance networks, since these also undergo constant formation and dissolution.

Regarding actions, the second uncertainty listed by Latour (2005), the assumption is that actions are not realized with complete conscious control. Actions should be understood as clusters, or a conglomerate of many agency groupings that must be slowly untangled. An action should remain a surprise, or an event. The notion of actor in the Actor-Network Theory is not the source of an action, but the target of a movement of vast array of entities focusing in its direction. The use of the word actor means that it is never clear who or what is acting at the moment in which we act, just as an actor on stage is never acting alone. There are many questions involved in an action, such as other actors, artifacts, time, emotions, available objects, etc. Thus, by definition, actions are disrupted. Actions are loaned, distributed, suggested, influenced, dominated, and translated.

Actors are constantly involved with others in the formation and destruction of groups. They attempt to provide explanations for their actions as well as others' actions. These aspects reemphasize the methodological differences found in investigations based on Actor-Network Theory: each interview, narrative and commentary, even if seemingly trivial, offers researchers a bewildering array of entities to explain hows and whys for any course of action. Due to this, researchers must pay close attention to the terms used by the actors and to all details involved in the action.

Pertaining to the third uncertainty, the nature of objects, Latour (2005) mentioned that when considering basic social abilities it is easy to understand that the connections they are capable of developing are always too weak to sustain the pressure that social theories like to endow in their social definition. A power relationship that mobilizes social abilities is limited to a short lifespan and transitory interactions. It is important to stress that when power is exercised for good, it is because it doesn't depend on social ties; when it has support from social ties, it isn't exercised for very long. Therefore, when social scientists talk about social ties, they should always refer to something that is difficult to alter over time and space, that has no inertia and is constantly renegotiated. It is so difficult 
to maintain asymmetries to entrench power relationships or reinforce inequalities, that effort is constantly directed to altering weak and decaying ties for other kinds of connections. If the social world were made through local interactions, it would possess a provisory, unstable, and chaotic nature, and would be unable to fully make sense of or articulate any highly differentiated scenario that could reject power and domination.

Bringing objects back to the normal course of action seems inoffensive and sufficient, because it is obvious that teapots boil water, knives cut meat, locks lock, etc. These verbs clearly designate actions. Latour (2005) explained that a good place to start analysis is with controversies between actors and agencies, because anything that changes the state of things by making a difference is an actor; or if still not configured, a surfactant. Some important questions should be raised: Does it make a difference in the course of action between another agent or not? Is there any process that allows for detecting such a difference? If the answer is yes, then these actors are participants in the course of action depending upon configuration. It is important to highlight that this doesn't mean that these participants determine the action. If this were the issue, then objects would merely be causes of effects transported via human action limited to an intermediary process. For Latour (2005), things can authorize, permit, concede, encourage, suggest, influence, impede, etc.

The Actor-Network Theory doesn't just assert that objects do things instead of human actors, it simply says that no social science can even begin without inquiry into who and what participates in actions. The Actor-Network Theory expands the list and modifies the ways and numbers of aggregated participants, projecting a concept of how they act as a lasting unit. The difference is in the following point: for Actor-Network Theory researchers, objects are crucial not only for being developing actors, but also because they explain the previously mentioned contrasting scenario; principally with respect to comprehensive powers of a society, immense asymmetries, and the overwhelming exercise of power (Latour, 2005). For Law (1992), virtually all interactions between human actors are mediated by objects.

Latour (2005) underlines that the Actor-Network Theory does not seek to establish symmetry between humans and non-humans. The interest in the object doesn't refer to any privilege given to objective material in opposition to subjective language, values, symbols, and feelings. Latour (2001) desires analytical clarity, but in ways that are not defined by the polemic tug-of-war between objects and subjects. The Actor-Network Theory doesn't intend to extend subjectivity to things, treat humans as objects, or label machines as social actors. Instead, it aims to avoid at all costs the subject-object distinction when discussing the dynamics between humans and non-humans. This theory's true proposal consists of attempting to capture the movements when a specific collective extends its social fabric to other entities. According to Brown, Lilley, Lim and Shukaitis (2010), the Actor-Network Theory's objective is to describe the process of delegating tasks that form and maintain a society to objects. This process refers to retelling the story made possible by relationships between humans and artifacts.

Latour (2005) stresses that working with Actor-Network Theory requires: an extension of the list of actors and agents; a deepening of conflicts about metaphysical practice; abandoning the artificial division between social and technical dimensions; searching for areas that have rarely been visited up until now; a new practice of encountering rewarding controversies; starting points that are more stable than absolute; and finally, an invitation to develop a new enigmatic use for shared metalanguage, social theory, and reflexivity with actors that are no longer considered mere informants.

Accordingly, Latour (2005) asserts that a researcher using Actor-Network Theory needs to transform the failure to provide a convincing social explanation from hard scientific facts in a proof. For this author, the failure of science in social explanation offers a great opportunity for social theory.

Latour (2005) believes a sociology of associations exists. More precisely: there isn't a society, a social sphere, or social ties, but rather translations between mediators that can generate traceable associations. Translation, for Latour (2005), means a relationship that doesn't include causality, but which supports two mediators in a coexistence. 
The fourth uncertainty refers to the mapping of scientific controversies concerning questions of interest to permit substituting for empiricism from top to bottom, and for the division between natural and social. A natural world composed of factual questions isn't the same as a world consisting of interesting questions. Due to this, it can't be used as a contrast for a symbolic-human-intentional social order. Latour (1994a, p. 12) elucidates that "the scientific facts are constructed, but they cannot be reduced to the social, because it is populated by mobilized objects to construct it". The last uncertainty is about studying the Actor-Network Theory itself; i.e. conjecturing risky explanations. Latour (2005) mentions that the idea is to bring the development of reports to the forefront. For this, two questions must be asked: What do we do when we trace social connections? Are we not, in reality, conjecturing explanations?

The grand research test for Actor-Network Theory is to know how many actors a researcher/composer is capable of dealing with as mediators and to what extent the researcher is capable of comprehending and articulating the social (Latour, 2005).

It is important to know that Actor-Network Theory is, in the first place, a principle of abstract projection to implant any form, not an arbitrary concrete decision about which forms should be on the map.

The first part (actor) reveals the strict space within which all world ingredients begin to emerge; the second part (network) can explain by which mediums, traces, routes, and types of information the world is being brought to these places, and after being transformed, is being forced back beyond its narrow walls (Latour, 2005). Whittle and Spicer (2008) argue that the Actor-Network Theory is clearly a useful method for understanding how actors are enrolled, how allegations of truth are constructed, and how objects and artifacts facilitate organized actions. Law (1992) suggests that the task of Actor-Network Theory is to characterize social networks in their heterogeneity, and explore how they are ordered according to patterns in order to generate effects such as organizations, inequalities and power. Next we include a table with the concepts of actor, actor networks, symmetry, and translation.

Table 1

Definitions of Key Concepts of the Actor-Network Theory

\section{Key Concepts of ANT Definitions}

1 Actor

The actor aspect of the expression actor-network isn't the source of an action, but rather the target of a vast array of entities aiming in its direction (Latour, 2005).

The term actor can be used to refer to a person, a plant, a machine, a meteorological system, or a microbe, for example (Whittle \& Spicer, 2008). For Law (1992): "an actor is a patterned network of heterogeneous relations, or an effect produced by such a network" (p. 5).

2 Actor Networks

The notion of actor networks strongly suggests that what seems to an observer to be an actor could, in fact, be an entire network (Czarniawska, 2006). Law (1992) believed that an actor is also, and always, a network. An actor network is perceived through common inclusion of human and non-human participants in a network through negotiation and translation processes (Hassard, Law, \& Lee, 1999).

3 Symmetry

Latour (1994a) defined symmetry based upon that which is preserved during transformations. This same author added that symmetry is a unified model of the social and natural worlds in which no entity (human or non-human) has priority or exists outside the network (Latour, 1996b). 


\section{Table 1 (continued)}

\begin{tabular}{|c|c|c|}
\hline & Key Concepts of ANT & Definitions \\
\hline 4 & Translation & $\begin{array}{l}\text { For Latour (2005), translation means a relationship that doesn't intimate causality, } \\
\text { but rather encourages two mediators in a coexistence. Translation "refers to all the } \\
\text { displacements among other actors whose mediation is essential to the occurrence } \\
\text { of any action. Instead of a rigid opposition between context and content, the } \\
\text { translation chains refer to the work by which the actors change, displace and } \\
\text { translate their several and contradictory interests" (Latour, 2001, p. 356). Law } \\
\text { (1992) explains translation as something which implies transformation and the } \\
\text { possibility of similarity; the possibility that something (for example, an actor) can } \\
\text { represent something else (for example, a network). }\end{array}$ \\
\hline
\end{tabular}

Note. Source: developed by the authors based upon: Czarniawska, B. (2006). Book review: Bruno Latour: reassembling the social: an introduction to actor-network theory. Organization Studies, 27(10), 1553-1557. doi: 10.1177/0170840606071164; Hassard, J., Law, J., \& Lee, N. (1999). Preface. Organization, 6(3), 387-390. doi: 10.1177/135050849963001; Latour, B. (1994a). On technical mediation - philosophy, sociology, genealogy. Common Knowledge, 3(2), 29-64; Latour, B. (1996b). On actor-network theory: a few clarifications. Soziale Welt, 47(4), 369-381; Latour, B. (2001). A esperança de Pandora: ensaios sobre a realidade dos estudos científicos. Bauru, SP: EDUSC; Latour, B. (2005). Reassembling the social: an introduction to actor-network-theory. New York: Oxford University Press Inc.; Law, J. (1992). Notes on the theory of the actor-network: ordering, strategy and heterogeneity. Systems Practice, 5(4), 379-393. doi: 10.1007/BF01059830; Whittle, A., \& Spicer, A. (2008). Is actor network theory critique? Organization Studies, 29(4), 611-629. doi: $10.1177 / 0170840607082223$

\section{Discussion about the Actor-Network Theory with Perspectives from Strategy as Social Practice and Governance Networks}

Regarding strategy and how it is understood, in this work as social practice, some authors (Tureta et al., 2006) suggest using the Actor-Network Theory as an interesting possibility to research strategy with a basis in the notion of social practices: "the practical daily activity in organizations gains importance through understanding the relationships between actors and is given form as they translate their contradictory interests, that is, converge their interests in a direction of a common goal" (Tureta et al., 2006, p. 2).

Tureta, Rosa and Santos (2006) explain that many practices consist of mutually stable relationships between human agents and different objects. These objects can be of various types, such as: machines, equipment, tools, computers, and others. It is important to stress that, from this perspective neither subject nor object are given primacy. What is important, and which has weight, is the subject-object relationship. These same authors assert that movement, continuity and fluidity are characteristics inherent to both strategy as social practice, where the focus is on the process, and also in the assumptions of the Actor-Network Theory, since this theory also pays close attention to the idea of movement.

A very logical thought made by these authors refers to understanding strategy from a ActorNetwork Theory logic. For them: "ANT represents an approach that traces the creation, evolution and dissolution of networks and objects that are constituted all the time. These objects can be understood as a strategy unto themselves" (Tureta et al., 2006, p. 6).

Based upon the possibility of exchange between strategizing and the Actor-Network Theory, Denis et al. (2007, p. 183) expressed the following articulation: "strategizing as a translation process: Building actor-networks".

Thus, organizational strategy can be considered equivalent to any technological artifact or scientific discovery. A specific strategy exists in the measure that its existence becomes real for a network of organizational actors (human and non-human) that support it. Then the strategizing process becomes a process of translation with all potential elements previewed in a translation process: (a) 
problematization; (b) interest; (c) registration; (d) mobilization towards a potentially (but not deterministically) irreversible well-defined strategy (Denis et al., 2007). Feigenbaum (2010) defines translation as a multifaceted interaction in which actors: (a) construct definitions and common meanings; (b) define representatives; (c) cooperate with each other towards individual or collective goals.

Denis et al. (2007) emphasize that by working with these two perspectives, strategizing and ANT, together, it is possible to investigate questions relevant to both theories. These include the mobilization of multiple meanings and linking multiple actors in dynamic ways.

With a basis in these questions, what stands out is that understanding strategic practices and activities is also essential for a full comprehension of governance networks (Rhodes, 1997, 2007). This is because the work, decisions, conflicts, policies, artifacts, etc., that permeate governance networks say as much about the actors that are involved as they do about their activities and daily practices. Understanding this labyrinth of questions certainly makes contributions to also understanding strategy as social practice, governance networks, and the Actor-Network Theory.

\section{Contributions to the Theory of Governance Networks}

\section{The role of the actor-network theory and human and non-human actors}

We believe that the notion of governance networks is supported by an interesting theoretical framework and that, as some authors also do (Kjaer, 2004; Rhodes, 1997, 2007), we propose to understand the nuances of governance according to the movements, interactions and changes that are actually happening. We deem this to be a more logical way to study governance mechanisms and networks, differently from older notions, such as hierarchical and market logics.

In all, we feel that, even though it is a relatively recent option that has promise to reveal interesting questions, the notion of governance networks could be even more robust. To this end, we believe that an interesting point worthy of discussion and to be taken into account in research about governance networks would be to introduce the notion of non-human actors from the Actor-Network Theory (Latour, 1994b, 1996a, 2001, 2005). This additional theoretical scope strengthens analysis, because just public and private human actors aren't sufficient to explain such a complex reality. We suggest that non-human actors can be very useful for explaining the social sphere of studied reality, seeing that, for Latour (2005) the social sphere is composed of human and non-human actors. Primacy isn't given to either, as both compose entities that are in constant movement forming heterogeneous networks and leaving traces that can be investigated. The principle is to look to non-humans when a new social characteristic emerges inexplicably, and look to the state of social relationships when a new and inexplicable type of object enters into the collective (Latour, 1994b).

Latour (2005) advises that if a research uses ANT, they should follow the actors themselves and be as innovative as possible in order to learn through the actors what the collective existence becomes in their hands, which methods they develop for making the collective existence fit, and which explanations better define the new associations they have been forced to establish.

The relevant questions for understanding this organizational reality are not clearly explained, and this generates confusion, misunderstandings, and ambiguities for the field. We hope that by investigating many of the questions that haven't yet been revealed, whether they haven't received due attention or simply because they are taken for granted, it is possible to better understand the governance networks and mechanisms of any organization studied. 


\section{The role of strategy and strategic outcomes}

Strategy is understood as something that organizations do and not something organizations have (Johnson et al., 2007). Strategy as practice offers a better grasp of what really happens in practice, seeing that at times what appears clear in a theory doesn't actually develop the same way in organizational reality (Montenegro, 2009). So, attention is given to the quotidian strategic activities and practices undertaken by actors.

Making a parallel with the notion of governance networks, we can affirm that this idea of strategy is aligned with the logic that permeates governance networks. Networks require interaction, movement, and process; i.e., the active participation of actors involved. Decision making and activities are continuously realized based on the ties between actors and the content they deal with.

Speaking of governance, strategic aspects enter in the scope of analysis as important elements to be investigated, because much of what is decided (and also what isn't) has a direct impact on how strategies are designed and executed and on strategic outcomes. Understanding content process, and strategic outcomes under the logic of strategy as practice seems to be a logical manner for learning about the many questions about governance.

We think that by mapping governance networks and mechanisms, identifying and understanding the actions of the actors involved, and with this developing explanations for these questions deals with strategic questions simultaneously. This is especially true for strategic outcomes, as governance and strategic outcomes are linked. Connolly and James (2011) emphasize that robust work about governance is being performed by various authors, however, works that deal with governance and performance are still incipient. These authors believe it is necessary to develop more studies pondering the integration of these themes. Furthermore, definition of strategic outcomes shouldn't be limited to economic outcomes, but also social and environmental outcomes (Bulgacov et al., 2007; Matitz, 2009).

\section{Methodological and Epistemological Reflections about Proposed Analytical Categories}

Given the theoretical articulations presented, we delineate some methodological and epistemological reflections (Table 2) about proposed analytical categories with the intent of mapping how these categories are being approached in recent literature and also to present possible analytical contributions that can be developed in empirical research. These reflections are also presented to support the analytical model that will be presented in sequence in Figure 1.

Table 2

\section{Proposed Analytical Categories and Their Methodological and Epistemological Reflections}

\begin{tabular}{|c|c|}
\hline Analytical Categories & Methodological and Epistemological Reflections \\
\hline Governance Networks & $\begin{array}{l}\text { There is a perception, based on theoretical discussion (Rhodes, 1997, 2007), that governance networks } \\
\text { understand a labyrinth of mechanisms and actors. For Kjaer (2011) governance refers to how political } \\
\text { actors affect formal and informal rules, and how they exist and survive with these rules. Given this, } \\
\text { investigating this phenomenon requires methodological caution in the sense of paying attention to the } \\
\text { nuances that are relevant for understanding these networks. This is because the mechanisms and actors } \\
\text { should be more evident in empirical research and it is up to the researcher to have the sensitivity to } \\
\text { observe and interpret what really composes these governance networks and how they function in the } \\
\text { daily life of studied organizations. Recent research into governance networks (Bevir, 2011; Kjaer, 2011; } \\
\text { Rhodes, 2011) have focused on deepening what was previously developed. They attempt to offer a } \\
\text { more detailed assessment of studied phenomena through the use of more interpretive methodology } \\
\text { found in qualitative research (ethnographies, narratives, etc.). This fact seems to demonstrate a } \\
\text { methodological necessity for a more accurate comprehension of a phenomena in order to reveal its } \\
\text { details. Stemming from this, this present research intends to follow the qualitative route and go even } \\
\text { further, in the sense of investigating not only human actors of this reality, but also non-human actors. } \\
\text { This is an approach missing from recent research into governance networks. }\end{array}$ \\
\hline
\end{tabular}




\title{
Table 2 (continued)
}

\author{
Analytical Categories Methodological and Epistemological Reflections \\ Human and Non- $\quad$ It is sometimes difficult to clearly define human and non-human actors, since they are often tangled, \\ human Actors and as mentioned by Latour (2005), not always easy to follow. In this article, we adopt Latour's \\ concept to fill the theoretical gap identified in governance network theory, because we believe that \\ people aren't unique in composing, shaping, and influencing reality. It is important to understand the \\ complete phenomenon, which demands including both human and non-human actors in research. In \\ some recent research using ANT (Alcadipani \& Tureta, 2008; Andrade, 2005; Camillis, 2012), \\ methodological measures were taken to identify all actors that are involved in a phenomenon, \\ especially non-human actors. Therefore, these works offer interesting methodological contributions \\ for the theory. Starting with this, it is clear that more empirical research needs to be developed to \\ corroborate what was asserted and discussed by these authors and also to further comprehension of \\ the phenomena studied with a basis in distinctive methodologies that might effectively contribute to \\ the field. As such, this work intends to contribute to methodological advances by proposing an \\ analytical scope that articulates between governance networks, human and non-human actors, and \\ strategic outcomes via QCA (Qualitative Comparative Analysis) (Ragin, 1987, 1992, 2000, 2008).
}

Close attention must be paid to strategic outcomes, especially in terms of methodology and defining what is and what isn't strategic in an organization. It is up to the research to identify the strategic

Strategic Outcomes management of investigated organizations, and from this, understand what are possible strategic outcomes. When focusing on educational organizations, the primary strategy is (or should be) offering high quality education to students. So it is imperative to understand what these organizations do to achieve this result. What are the strategic activities and practices that lead to a good result in teaching? This analytical perspective is guided by the assumptions that approach strategy as social practice and seeks to understand the daily happenings of actors involved in the strategy (or strategies) of a studied organization. An empirical development based on the perspective of strategic outcomes (Bulgacov et al., 2007; Matitz, 2009) can contribute to this theory through diverse methodologies with the intent of revealing the nuances about both the theory itself and the field of research.

\begin{abstract}
Note. Source: Developed by the authors based upon Alcadipani, R., \& Tureta, C. (2008, junho). Pós-estruturalismo e análise das organizações: a contribuição da teoria ator-rede. Anais do Encontro de Estudos Organizacionais, Belo Horizonte, MG, Brazil, 5; Andrade, J. A. (2005, setembro). Redes de atores: uma nova forma de gestão das políticas públicas no Brasil? Anais do Encontro Nacional da Associação Nacional de Pós-Graduação e Pesquisa em Administração, Brasília, DF, Brazil, 29; Bevir, M. (2011). Public administration as storytelling. Public Administration, 89(1), 183-195. doi: 10.1111/j.14679299.2011.01908.x; Camillis, P. K. de (2012, maio). Seguindo os atores e construindo a teoria ator-rede como método: algumas possibilidades. Anais do Encontro de Estudos Organizacionais, Curitiba, PR, Brazil, 7; Kjaer, A. (2011). Rhodes' contribution to governance theory: praise, criticism and the future governance debate. Public Administration, 89(1), 101-113. doi: 10.1111/j.1467-9299.2011.01903.x; Latour, B. (2005). Reassembling the social: an introduction to Actor-networktheory. New York: Oxford University Press Inc.; Ragin, C. C. (1987). The comparative method: moving beyond qualitative and quantitative strategies. Berkeley, Los Angeles, London: University of California Press; Ragin, C. C. (1992). What is a case? Exploring the foundations of social inquiry. New York: Cambridge University Press; Ragin, C. C. (2000). Fuzzy-set social science. Chicago: University of Chicago Press; Ragin, C. C. (2008). Redesigning social inquiry - fuzzy sets and beyond. Chicago: University of Chicago Press; Rhodes, R. (1997). Understanding governance: policy networks, governance, reflexivity and accountability. Maidenhead, GB, Philadelphia, US: Open University Press; Rhodes, R. (2007). Understanding governance: ten years on. Organization Studies, 28(8), 1243-1264. doi: 10.1177/0170840607076586; Rhodes, R. (2011). Thinking on: a career in public administration. Public Administration, 89(1), 196-212. doi: 10.1111/j.14679299.2011.01898.x
\end{abstract}

\section{The Meaning of Action}

According to Whittle and Spicer (2008), the ANT is a useful method to understand how actors are connected in the networks, how allegations about the truth are constructed and how the objects and artifacts enable organized action. The actor part of the actor-network expression is not the source of an action, but the aim in movement of an array disposition of entities aiming in one direction. To use the word actor means that it is never clear who or what is acting in the moment that we act because an actor on stage is never acting alone (Latour, 2005). Therefore, who is responsible for the action? Both humans and non-humans (Latour, 1994b).

According to Latour (2005), action is not done with total conscious control. An action should be seen as a knot, a conglomerate of many groups of agency which have to be slowly untangled. The 
action should remain as a surprise, a mediation, an event. Latour (2001) believes that maybe intentional action and intentionality are neither properties of objects nor of humans. They are properties of institutions, of apparels, and others. The objects that exist simply as objects, apart from a collective life, are unknown.

There are many issues involved with action, such as other actors, artifacts, time, emotions, disposition of objects, and others (Latour, 2005). According to Law (1992), almost every interaction of human beings with other human beings is mediated by objects.

For the governance network theory, a networks work presupposes a capacity of selforganization, efficiency, and action by the actors involved. In other words, networks do not substitute for the action of single organizations. It is rare that efficient networks will emerge from cooperation among weak individual organizations (Messner \& Meyer-Stamer, 2000).

It is important to highlight that we understand that the governance network theory presupposes self-organization, but, when dealing with action, we consider that there is not such an autonomy concerning action because, according to the definition of social we presented in the introduction of this paper, which says that there is not a dichotomy between natural and social and that the material matters are part of this natural/social world, we cannot think of action as something done only by human actors and we cannot think of action as something done only by non-human actors. This is one of the reasons we believe that the governance network theory should embrace the notion of social in its wholeness, which means including non-humans actors in its theoretical scope.

Concerning the perspective of social practice, Certeau (1984) highlights that social practices are internal manipulations of a system (of language or of an established order). So, social practice constitutes individual agents that act and interact spontaneously, most of the time, in a self-referential way in order to overcome immediate problems and obstacles without the necessity of a theoretical distance, conscious deliberation or pre-determined action plan. From this perspective, there is no distinction presupposed between individual and society, there is no dualism between mind and matter, and there is no distance a priori between thought and action: these matters are considered secondary distinctions generated by the social practices per se (Chia \& Rasche, 2010).

The practice approach breaks with methodological individualism by emphasizing that activities need to be understood as enabled or constrained by the prevailing practices in the field in question. Thus, a practice approach to strategy should not merely focus on the behaviors or actions of managers but seek to examine how these behaviors or actions are linked to prevailing practices. Specific behaviors or actions are closely linked with or mediated by material resources (Golsorkhi et al., 2010).

\section{Final Considerations}

Given what was discussed in this article, we believe there is a possibility for theoretical advancement providing construction of a theoretical proposal. This assumes that governance network theory will be more robust if it considers within its scope not only human actors (private and public) but also non-human actors (objects, artifacts, plans, narratives, reports, etc.). The assumption is that by including non-human actors, explanatory powers will be amplified and questions that are often taken for granted by the organizations studied will be revealed, discussed and considered. We also hope to offer contributions to the strategic outcomes approach, since the theoretical framework developed involves strategic questions, especially regarding strategic outcomes.

This inclusion of non-human actors in the analytical scope offers more robust elucidation of phenomena, especially those not widely covered in the organizational studies and strategy fields. We believe that the role of non-human actors is essential for understanding organizational reality, since the social sphere is formed by imbrications of human and non-human actors. Materials such as artifacts, objects, technologies, plans, etc. are important for shedding light on relationships between people. 
Because relationships involve these objects as mediators, they are also endowed with action and interfere in people's decisions, attitudes and behaviors.

Thus, a possible empirical development would be, grounded in Actor-Network Theory, to understand and analyze strategic outcomes and governance networks via the actions and relationships between the multiple actors (human and non-human) involved. Strategic actions occur during the strategizing process and are configured as a translation process that generates governance networks to produce a partially stabilized order within the continuous construction of mediating links.

We know that this is an innovative proposal which requires considerable investigative effort, as much for the theories chosen as part of the theoretical framework as for the field of investigation. The theories are suggested by some authors (Golsorkhi et al., 2010; Tureta et al., 2006) as interesting, but highly complex and at times controversial. The governance network theory is the subject of intensive discourse in the area (Kjaer, 2004; Rhodes, 1997, 2007, 2011; Sorensen \& Torfing, 2005) with divergent opinions.

The questions of governance and strategic outcomes are important for explaining organizational reality. Deriving from research in the area, it is possible to perceive that these questions need to be discussed so that comprehension can advance towards achieving positive and promising outcomes.

This theoretical essay has a role of contributing to discourse in the strategy and organizational studies areas, in order to generate questions that seem to be healthy (and necessary) for advancing research into the chosen themes. Additionally, it is important to offer some suggestions for future research, these include: (a) work with the notion of governance, its networks and mechanisms, in schools from different Brazilian states in order to highlight regional differences; (b) undertake a study of governance and strategic outcomes in public and private educational organizations to display convergent and divergent aspects between the two realities; (c) perform research that takes different levels of governance into consideration, such as micro, macro, and/or multilevel; (d) carry out crosscultural investigation into governance, human and non-human actors, and strategic outcomes in different countries.

\section{References}

Alcadipani, R., \& Tureta, C. (2008, junho). Pós-estruturalismo e análise das organizações: a contribuição da teoria ator-rede. Anais do Encontro de Estudos Organizacionais, Belo Horizonte, MG, Brazil, 5.

Andrade, J. A. (2005, setembro). Redes de atores: uma nova forma de gestão das políticas públicas no Brasil? Anais do Encontro Nacional da Associação Nacional de Pós-Graduação e Pesquisa em Administração, Brasília, DF, Brazil, 29.

Barad, K. (2003). Posthumanist performativity: toward an understanding of how matter comes to matter. Signs, 28(3), 801-831. doi: 10.1086/345321

Bevir, M. (2011). Public administration as storytelling. Public Administration, 89(1), 183-195. doi: 10.1111/j.1467-9299.2011.01908.x

Brown, S. D., Lilley, S., Lim, M., \& Shukaitis, S. (2010). The state of things. Ephemera, 10(2), 90-94.

Bulgacov, S., Souza, Q., Prohmann, J., Coser, C., \& Baraniuk, J. (2007). Administração estratégica: teoria e prática (P. J. Pires, Col.). São Paulo: Atlas.

Calás, M., \& Smircich, L. (1999). Past postmodernism? Reflection and tentative directions. Academy of Management Review, 24(4), 649-671. doi: 10.2307/259347 
Callon, M., \& Latour, B. (1981). Unscrewing the big leviathans: how do actors macrostructure reality. In K. Knorr \& A. Cicourel (Eds.), Advances in Social Theory and Methodology: Toward an Integration of Micro and Macro Sociologies (pp. 277-303). London: Routledge.

Camillis, P. K. de (2012, maio). Seguindo os atores e construindo a teoria ator-rede como método: algumas possibilidades. Anais do Encontro de Estudos Organizacionais, Curitiba, PR, Brazil, 7.

Certeau, M. de (1984). The practice of everyday life. Berkeley: University of California Press.

Chia, R., \& Rasche, A. (2010). Epistemological alternatives for researching strategy as practice: building and dwelling worldviews. In D. Golsorkhi, L. Rouleau, D. Seidl, \& E. Vaara (Eds.), Cambridge handbook of strategy as practice (pp. 34-43). New York: Cambridge University Press.

Connolly, M., \& James, C. (2011). Reflections on developments in school governance: international perspectives on school governing under pressure. Educational Management Administration \& Leadership, 39(4), 501-509. doi: 10.1177/1741143211406560

Czarniawska, B. (2003). Social constructionism and organization studies. In R. Westwood \& S. Clegg (Eds.), Debating organization: point-counterpoint in organization studies (pp. 128-139). Malden, USA, Oxford, UK, Melbourne, Australia and Berlin, Germany: Blackwell Publishing.

Czarniawska, B. (2006). Book review: Bruno Latour: reassembling the social: an introduction to actornetwork theory. Organization Studies, 27(10), 1553-1557. doi: 10.1177/0170840606071164

Denis, J. L., Langley, A., \& Rouleau, L. (2007). Strategizing in pluralistic contexts: rethinking theoretical frames. Human Relations, 60(1), 179-215. doi: 10.1177/0018726707075288

Ezzamel, M., \& Reed, M. (2008). Governance: a code of multiple colours. Human Relations, 61(5), 597-615. doi: 10.1177/0018726708092316

Feigenbaum, A. (2010). Concrete needs no metaphor: globalized fences as sites of political struggle. Ephemera, 10(2), 119-133. $\quad$ Retrieved from http://www.ephemerajournal.org/contribution/concrete-needs-no-metaphor-globalized-fencessites-political-struggle

Golsorkhi, D., Rouleau, L., Seidl, D., \& Vaara, E. (Eds.) (2010). Cambridge handbook of strategy as practice. New York: Cambridge University Press.

Grand, S., Rüegg-Stürm, J., \& Arx, W. (2010). Constructivist epistemologies in strategy as practice research. In D. Golsorkhi, L. Rouleau, D. Seidl, \& E. Vaara (Eds.), Cambridge handbook of strategy as practice (pp. 63-78). New York: Cambridge University Press.

Hassard, J., Law, J., \& Lee, N. (1999). Preface. Organization, 6(3), 387-390. doi: $10.1177 / 135050849963001$

Hirst, P., \& Thompson, G. (1995). Globalization and the future of the nation state. Economy and Society, 24(3), 408-442. doi: 10.1080/03085149500000017

Jarzabkowski, P. (2010). An activity-theory approach to strategy as practice. In D. Golsorkhi, L. Rouleau, D. Seidl, \& E. Vaara (Eds.), Cambridge handbook of strategy as practice (pp. 127140). New York: Cambridge University Press.

Johnson, G., Langley, A., Melin, L., \& Whittington, R. (2007). Strategy as practice: research directions and resources. New York: Cambridge University Press.

Kjaer, A. (2004). Governance. Cambridge, UK and Malden, USA: Key Concepts. 
Kjaer, A. (2011). Rhodes' contribution to governance theory: praise, criticism and the future governance debate. Public Administration, 89(1), 101-113. doi: 10.1111/j.14679299.2011.01903.x

Latour, B. (1994b). Jamais fomos modernos: ensaio de antropologia simétrica. Rio de Janeiro: Editora 34.

Latour, B. (1994a). On technical mediation - philosophy, sociology, genealogy. Common Knowledge, $3(2), 29-64$.

Latour, B. (1996b). On actor-network theory: a few clarifications. Soziale Welt, 47(4), 369-381.

Latour, B. (1996a). On interobjectivity. Mind, Culture and Activity, 3(4), 228-245. doi: 10.1207/s15327884mca0304_2

Latour, B. (2000). Ciência em ação: como seguir cientistas e engenheiros sociedade afora. São Paulo: Editora UNESP.

Latour, B. (2001). A esperança de Pandora: ensaios sobre a realidade dos estudos científicos. Bauru, SP: EDUSC.

Latour, B. (2004). Nonhumans. In S. Harrison, S. Pile, \& N. Thrift (Eds.), Patterned ground: entanglements of nature and culture (pp. 224-227). London: Reaktion Books.

Latour, B. (2005). Reassembling the social: an introduction to Actor-network-theory. New York: Oxford University Press Inc.

Law, J. (1992). Notes on the theory of the actor-network: ordering, strategy and heterogeneity. Systems Practice, 5(4), 379-393. doi: 10.1007/BF01059830

Matitz, Q. (2009). Aspectos semânticos, formais e funcionais do conceito desempenho em estudos organizacionais e estratégia: um modelo analítico (Tese de doutorado). Universidade Federal do Paraná, Curitiba, PR, Brazil.

McLean, C., \& Quattrone, P. (2006, May). On theorizing the object: insights from Gabriel Tarde. Proceedings of the Meeting Gabriel Tarde: Economy, Psychology and Invention Conference, London, UK.

Messner, D., \& Meyer-Stamer, J. (2000, February). Governance and networks. Tools to study the dynamics of clusters and global value chains. Proceedings of the IDS/INEF Project The Impact of Global and Local Governance on Industrial Upgrading, Duisburg, German.

Montenegro, L. (2009). Construção de sentidos (sensemaking) em práticas de um processo estratégico: um estudo comparativo em duas instituições de ensino superior do Estado do Paraná (Dissertação de mestrado). Universidade Federal do Paraná, Curitiba, PR, Brazil.

Olowu, D. (2002). Introduction - governance and public administration in the 21st century: a research and training prospectus. International Review of Administrative Sciences, 68(3), 345-353. doi: $10.1177 / 0020852302683003$

Orlikowski, W., \& Scott, S. (2008). Sociomateriality: challenging the separation of technology, work and organization. The Academy of Management Annals, 2(1), 433-474. doi: $10.1080 / 19416520802211644$

Peters, G. (2000). Governance and comparative politics. In J. Pierre (Ed.), Debating governance: authority, steering, and democracy (pp. 36-53). Oxford: Oxford University Press. 
Ragin, C. C. (1987). The comparative method: moving beyond qualitative and quantitative strategies. Berkeley, Los Angeles, London: University of California Press.

Ragin, C. C. (1992). What is a case? Exploring the foundations of social inquiry. New York: Cambridge University Press.

Ragin, C. C. (2000). Fuzzy-set social science. Chicago: University of Chicago Press.

Ragin, C. C. (2008). Redesigning social inquiry - fuzzy sets and beyond. Chicago: University of Chicago Press.

Rhodes, R. (1997). Understanding governance: policy networks, governance, reflexivity and accountability. Buckingham, Philadelphia: Open University Press.

Rhodes, R. (2007). Understanding governance: ten years on. Organization Studies, 28(8), 1243-1264. doi: $10.1177 / 0170840607076586$

Rhodes, R. (2011). Thinking on: a career in public administration. Public Administration, 89(1), 196212. doi: $10.1111 / \mathrm{j} .1467-9299.2011 .01898 . x$

Slife, B. (2004). Taking practice seriously: toward a relational ontology. Journal of Theoretical and Philosophical Psychology, 24(2), 157-178. doi: 10.1037/h0091239

Sorensen, E., \& Torfing, J. (2005). The democratic anchorage of governance networks. Scandinavian Political Studies, 28(3), 195-218. doi: 10.1111/j.1467-9477.2005.00129.x

Suchman, L. (2007). Human-machine reconfigurations: plans and situated actions. Cambridge, UK: Cambridge University Press.

Tsoukas, H. (2010). Practice, strategy making and intentionality: a Heideggerian onto-epistemology for strategy as practice. In D. Golsorkhi, L. Rouleau, D. Seidl, \& E. Vaara (Eds.), Cambridge handbook of strategy as practice (pp. 47-62). New York: Cambridge University Press.

Tureta, C., Rosa, A., \& Santos, L. (2006, setembro). Estratégia como prática social e Actor-Network Theory: uma possível conversação para o estudo da estratégia. Anais do Encontro Nacional da Associação Nacional de Pós-Graduação e Pesquisa em Administração, Salvador, BA, Brazil, 30 .

Wessells, A. (2007). Book review - reassembling the social: an introduction to Actor-Network Theory by Bruno Latour. International Public Management Journal, 10(3), 351-356. doi: 10.1080/10967490701515606

Whittle, A., \& Spicer, A. (2008). Is actor network theory critique? Organization Studies, 29(4), 611629. doi: $10.1177 / 0170840607082223$

Yanow, D. (2006). Thinking interpretively: philosophical presuppositions and the human sciences. In D. Yanow \& P. Schwartz-Shea (Eds.), Interpretation and Method: Empirical research method and the interpretive turn (pp. 5-26). New York: M.E. Sharp. 